Agro-Science Journal of Tropical Agriculture, Food, Environment and Extension ISSN 1119-7455 Volume 9 Number 1 January $2010 \quad$ pp. $18-23$

\title{
ASSESSMENT OF THE GESTATION PERIOD AND ECONOMIC YIELD OF AFRICAN BREADFRUIT, TRECULIA AFRICANA, VAR. africana DECNE, MORACEAE
}

Nzekwe $^{1}, U^{-}$, Ojeifor ${ }^{2}$, I.M. and Nworie ${ }^{3}$, H. E.

${ }^{1}$ Department of Botany, University of Nigeria, Nsukka, Nigeria.

${ }^{2}$ Department of Agronomy, Delta State University, Asaba Campus, Nigeria

${ }^{3}$ National Horticultural Research Institute (NIHORT), Okigwe, Imo State, Nigeria.

\begin{abstract}
Seedlings of African breadfruit, Treculia africana var. africana Decne, were established in a two hectare plot, adopting $10 \times 10 \mathrm{~m}$ spacing. The seedlings were later budded in January 1995 using budwoods obtained when the parent stocks (already fruiting trees) were in flowers. Observations were made on the gestation period of the budded seedlings and the pattern of flowering and fruiting. The study lasted for 12 year (1994-2005). Fruits produced by each tree were recorded and then processed for the seeds, which were sun-dried for 2hours before disposal. The price at disposal was based on the standard for disposing agricultural produce and prevailing market price in the South Eastern States. The results showed that the trees took 3-4 years to begin flower and fruit production. Majority of the flowers produced in the first phase of reproduction aborted but persisted till fruit production in the subsequent years. Seed yield increased from $11.54 \mathrm{~kg}$ in 1998 to $12.46 \mathrm{~kg}$ in 2005 . Revenue accruing from the sale of the seeds also increased from $\$ 304.70$ in 1998 to 2,470 in 2005 . With a standard tree density of 100trees/ha., adopting $10 \times 10 \mathrm{~m}$ spacing, mean revenue as high as $\$ 118,340.00$ would be realized from 20 trees. Such revenue can be relied upon as a sustainable source of alleviating poverty particularly among the rural farmers.
\end{abstract}

Key words: Treculia africana, gestation period, seed yield, revenue generating capacity.

\section{NTRODUCTION}

African bread fruit, Treculia africana var. africana, family Moraceae, is a food tree crop of nutritional importance (Okafor, 1983). The trees are planted some distance away from residential areas to avert the danger posed by its heavy, large fruit which is not traditionally harvested but allowed to ripen and drop from the tree (Mabo, et al., 1988, Mbakwe, 2005). In Nigeria, the plant is mainly grown in the Eastern States, where it is locally recognized as "Ukwa".

The tree is semi deciduous. It fruits all the year, with period of heavy fruiting between February and August alternating with that of light fruiting, between September and January (Okafor, 1985). The tree bears its fruits on the main trunk and on the big lateral branches. The fruits vary in size but are generally spherical large, rough textured, green when juvenile and greenish-yellow when ripe, pulpy and covered with soft, spinous structure (Baiyeri and Mbah, 2006). The fruit weighs about $10-25 \mathrm{~kg}$ with a diameter of 10.5-20.5cm (Nzekwe, et al., 1993).

The desired part of the plant for food is the seed which is variously prepared and eaten (Okafor et al., 1997, Baiyeri and Mbah, 2006) Ejiofor and Okafor (1997) reported the presence of protein, $14.6 \%$, carbohydrate, $69.08 \%$, fat and oil, $11.3 \%$ and varying percentages of vitamins crude fibre, mineral salts and water in the seed. NIHORT (2008, personal communication) reported that $3.8 \mathrm{~kg}$ of the seed sell for as much as N750 (seven hundred and fifty naira). Despite the important role the species plays in the economy of the rural and urban dwellers, its gestation period and revenue generating capacity are not yet well known. The desire to contribute to knowledge aroused our interest to study the gestation period, pattern of fruit/seed production and revenue generating capacity per tree per year of this plant. The aims of the study are therefore to ascertain the gestation period of budded seedlings of African bread fruit, to evaluate the pattern of its fruit production and to assess the revenue generating capacity of the plant (per tree per year) from the commencement of flowering and fruiting.

\section{MATERIALS AND METHODS}

Two hectares of land were prepared for planting, using a tractor for slashing, harrowing and ploughing. The prepared land was marked adopting $10 \times 10 \mathrm{~m}$ spacing, after which holes 10 $15 \mathrm{~cm}$ deep were made for planting the seedlings of Treculia africana. Three months old seedlings of Treculia africana var. africana raised in 
medium size polyethylene bags filled with 2:1:1 mixture of composted poultry droppings, top forest soil and sawdust were planted in the prepared land at the rate of one seedling per hole. Six months after planting, the seedling were budded in the field adopting patch budding technique. Based on earlier reports, budwood used in budding the seedlings were obtained when the parent stock (Plate 1) were in flower (January, 1995). Mbakwe (2005) reported that at this reproductive phase of the plant budwood obtained contained flower inducing substances, hence such budded seedlings could reproduce early. The budded seedlings were watered using water sprinklers that distributed water pumped from lbii river near the experimental sight to the seedlings. Each watering period lasted for 3hours. Watering was done at interval of 2 days and in the morning. The experiment was carried out at National Horticultural Research Institute (NIHORT), Okigwe and lasted from 1994 to 2005.

The two hectares of land planted up with the seedlings of Treculia were split into four parts/plots and each part was considered a replication. Each replication contained 50 budded seedlings. Observations were made on the seedlings for flower production at monthly interval. Apart from $5 \mathrm{~kg}$ of animal dung that was applied to each of the budded seedlings under observation in the first 2 years, no other fertilizer imput was made. Weeds in the 2 ha. plot of land were maintained first by slashing the plot with a tractor, followed by hoe weeding around the seedlings. This was done twice; in January and in November of each year, till 12years this study lasted.

For the third years growth record in the field, five budded plants (Treculia) were selected from each replication for further observations and data were collected on the plant's gestation period, seed production and revenue yielding capacity. Based on earlier reports (Mbakwe, 2005), trees that were refoliating were not selected since such trees might possibly not flower within the season. Selected trees were labeled and numbered 1-20.

Fruits produced (Plate 2) were allowed to drop from the trees that produced them. The fruits were left for 2-3 weeks to allow them ferment to an extent that could enhance the extraction of the seeds (Plate 3), following the process described by Baiyeri and Mbah, (2006). Seeds obtained from the fruits of each tree were sun-dried for 2 hours before disposal. The price of the sun-dried seeds at disposal was based on the standard for disposing agricultural produce. The price of specified quantity of seeds was determined by using a plastic bucket containing $3.8 \mathrm{~kg}$ of Treculia seeds. Market survey of South Eastern States of Nigeria showed that $3.8 \mathrm{~kg}$ of
Treculia seeds sold at $\$ 750$. At the end of each year, seed yield $(\mathrm{kg})$ and revenue accruing from the sale of the seeds in Nigerian Naira ( $\#$ ) were worked out per tree per year. Data obtained at the end of the study from seed yield and accrued revenue were subjected to descriptive statistical analysis.

\section{RESULTS}

Table 1 represents the seed yield per tree per year throughout the 12 year duration of this study. Flower production was observed on 8 (40\%) out of the 20 trees 3-4 years after budding (from 1996 - 1997), followed by those of the remaining 12 trees in the following year. The pattern of flower production in all the trees in the first reproductive phase showed variations, in that flowers were not produced on all the branches of the trees that flowered. Some trees produced few clusters of flowers on one or two of their branches while other trees produced few flowers on four to six of their branches. The results further showed that all the flowers produced by the trees in their first reproductive phase experienced heavy abortion, resulting in non-seed yield. The results also showed that in the second year of reproduction, the trees flowered profusely on all their branches. The flowers persisted till fruit formation and maturity. The fruits that persisted till ripening were small in size and poorly filled with quality seeds. The results showed that the trees started producing bigger fruits filled with small quantity of commercially valuable seeds three years after the first fruiting (1998).

The total seed production per tree per year as shown in Table I, increased with time(years) throughout the 12 years of this study. The coefficient of variation of seed yield decreased with time (years). The early period of seed yield (1998-1999) had the highest coefficient of variation, while the later steady period of seed yield (2000-2005) had the least.

The market price of the seeds of Treculia increased with time (years), from \#372.11 per tree per year in 1998 to \$2,470.36 in 2005. The results further showed that total revenue accruing from the 20 trees per year increased from $\$ 7,74.1$ in1998 to $\$ 49,407.20$ in 2005. It was further observed that high revenue yield of the trees commenced from 5 years after the first fruit production and increased with time (years) as shown in Table 2. 


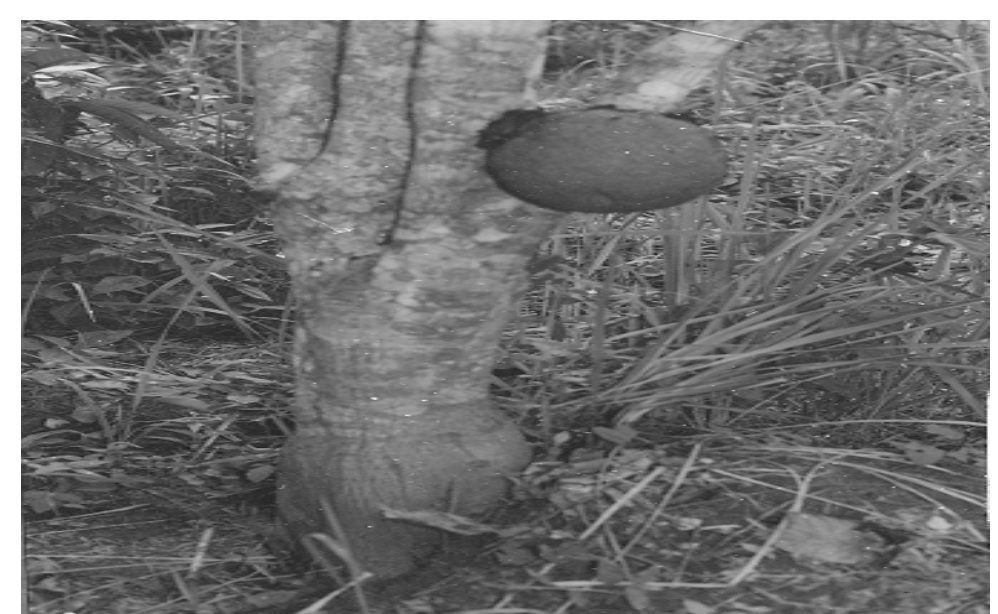

Plate 1: Treculia africana tree bearing fruit on the main trunk

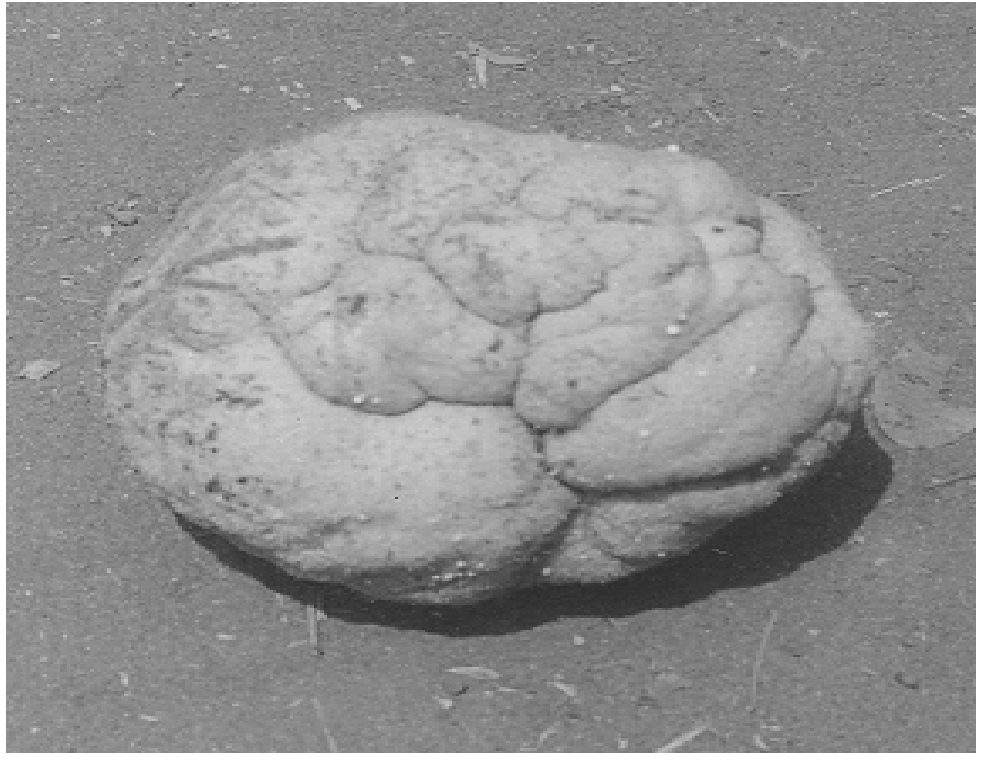

Plate 2: Treculia africana Fruit

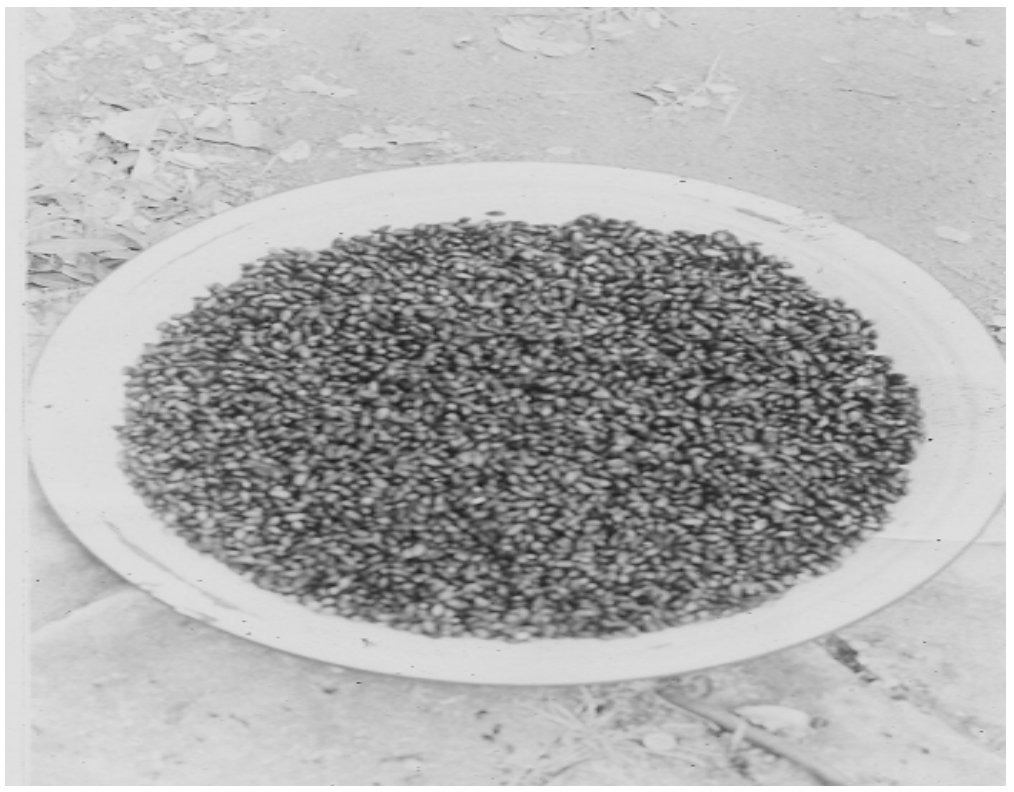

Plate 3: Treculia seeds 
Table 1: Seed Production of Treculia africana var. Africana Weight

\begin{tabular}{|c|c|c|c|c|c|c|c|c|c|c|}
\hline Trees S/N & 1996 & 1997 & 1998 & 1999 & 2000 & 2001 & 2002 & 2003 & 2004 & 2005 \\
\hline 1 & $\mathrm{X}$ & $\#$ & 1.3 & 2.6 & 3.0 & 4.6 & 6.4 & 8.7 & 11.8 & 12.6 \\
\hline 2 & $\mathrm{X}$ & \# & 1.5 & 2.8 & 3.2 & 4.8 & 6.8 & 8.6 & 11.6 & 12.4 \\
\hline 3 & $\mathrm{X}$ & \# & 1.6 & 2.4 & 3.2 & 5.2 & 8.2 & 102 & 11.8 & 12.5 \\
\hline 4 & - & $\mathrm{X}$ & \# & 1.5 & 2.8 & 4.0 & 6.6 & 9.2 & 11.6 & 12.5 \\
\hline 5 & $\mathrm{X}$ & $\#$ & 2.6 & 2.8 & 3.4 & 4.8 & 7.2 & 10.2 & 12.2 & 12.8 \\
\hline 6 & $\mathrm{X}$ & \# & 1.2 & 2.6 & 3.6 & 5.0 & 8.4 & 11.1 & 12.6 & 12.9 \\
\hline 7 & - & $\mathrm{X}$ & \# & 1.4 & 2.6 & 3.8 & 5.0 & 9.4 & 10.6 & 12.0 \\
\hline 8 & - & $\mathrm{X}$ & \# & 1.2 & 2.2 & 3.9 & 5.6 & 9.6 & 11.2 & 12.6 \\
\hline 9 & - & $\mathrm{X}$ & \# & 1.4 & 2.5 & 3.8 & 5.8 & 9.4 & 11.2 & 12.2 \\
\hline 10 & - & $\mathrm{X}$ & \# & 1.5 & 2.8 & 3.4 & 5.6 & 9.2 & 11.4 & 12.4 \\
\hline 11 & $\mathrm{X}$ & \# & 1.4 & 2.5 & 3.0 & 4.6 & 7.4 & 11.5 & 12.6 & 12.9 \\
\hline 12 & - & $\mathrm{X}$ & \# & 1.4 & 2.4 & 3.8 & 6.0 & 10.2 & 12.5 & 12.8 \\
\hline 13 & - & $\mathrm{X}$ & \# & 1.5 & 2.3 & 3.8 & 5.8 & 9.8 & 10.4 & 12.0 \\
\hline 14 & - & $\mathrm{X}$ & \# & 1.3 & 2.3 & 3.5 & 5.6 & 9.6 & 10.6 & 12.2 \\
\hline 15 & $\mathrm{X}$ & \# & 1.3 & 2.5 & 3.4 & 4.8 & 6.2 & 9.8 & 10.6 & 12.4 \\
\hline 16 & - & $\mathrm{X}$ & \# & 1.4 & 2.6 & 3.6 & 5.2 & 8.6 & 10.0 & 12.4 \\
\hline 17 & - & $\mathrm{X}$ & \# & 1.5 & 2.4 & 3.4 & 5.6 & 8.5 & 10.5 & 12.6 \\
\hline 18 & $\mathrm{X}$ & \# & 1.4 & 2.5 & 3.5 & 4.6 & 7.4 & 10.5 & 11.8 & 12.8 \\
\hline 19 & - & $\mathrm{X}$ & \# & 1.5 & 2.6 & 3.6 & 5.4 & 9.4 & 10.6 & 11.8 \\
\hline 20 & - & $\mathrm{X}$ & \# & 1.4 & 2.4 & 3.4 & 5.1 & 9.3 & 11.5 & 12.8 \\
\hline- & & & 1.54 & 1.89 & 2.81 & 4.12 & 6.27 & 9.64 & 11.33 & 12.46 \\
\hline X & & & & & & & & & & \\
\hline SE & & & 0.42 & 0.50 & 0.44 & 0.59 & 0.98 & 0.79 & 0.76 & 0.31 \\
\hline $\mathrm{CV}(\%)$ & & & 27.15 & 30.91 & 15.51 & 14.33 & 15.66 & 8.15 & 6.68 & 2.48 \\
\hline
\end{tabular}

Table 2: Revenue Yield (\$) of Treculia africana var. african amt. (\$)/tree Per Year

\begin{tabular}{|c|c|c|c|c|c|c|c|c|c|c|}
\hline Trees S/N & 1996 & 1997 & 1998 & 1999 & 2000 & 2001 & 2002 & 2003 & 2004 & 2005 \\
\hline 1 & & & 256.6 & $5 ` 13.2$ & 592.2 & 908.0 & $1,263.4$ & 1,7174 & $2,329.3$ & $2,487.2$ \\
\hline 2 & & & 296.1 & 552.27 & 631.7 & 947.5 & $1,342.3$ & $1,697.6$ & $2,289.8$ & $2,447.8$ \\
\hline 3 & & & 315.8 & 473.8 & 631.7 & 1026.5 & $1,618.7$ & $2,013.5$ & $2,329.3$ & $2,467.5$ \\
\hline 4 & - & - & - & 296.1 & 552.7 & 789.6 & $1,302.8$ & $1,816.1$ & $2,289.8$ & $2,467.5$ \\
\hline 5 & & & 513.2 & 552.7 & 671.2 & 947.5 & $1,421.1$ & $2,013.5$ & $2,408.3$ & $2,506.7$ \\
\hline 6 & & & 236.8 & 5132 & 710.6 & 987.0 & $1,658.2$ & $2,191.1$ & $2,487.2$ & $2,546.5$ \\
\hline 7 & - & - & - & 276.4 & 513.2 & 750.1 & 987.0 & $1,855.5$ & $2,092.4$ & $2,358.0$ \\
\hline 8 & - & - & - & 236.9 & 434.3 & 769.9 & $1,105.4$ & $1,895.0$ & $2,210.9$ & $2,487.2$ \\
\hline 9 & - & - & - & 276.4 & 493.5 & 750.1 & $1,144.9$ & $1,855.5$ & $2,210.9$ & $2,408.3$ \\
\hline 10 & - & - & - & 296.1 & 552.7 & 671.2 & $1,105.4$ & $1,816.1$ & $1,250.4$ & $2,447.8$ \\
\hline 11 & - & - & 276.4 & 493.5 & 513.2 & 908.6 & $1,460.8$ & $2,270.0$ & $2,487.9$ & $2,546.5$ \\
\hline 12 & - & - & - & 276.4 & 473.8 & 750.1 & $1,184.4$ & $2,013.5$ & $2,467.5$ & $2,506.7$ \\
\hline 13 & - & - & - & 296.1 & 454.0 & 750.1 & $1,144.9$ & $1,934.5$ & $2,053.0$ & $2,487.2$ \\
\hline 14 & - & - & - & 256.6 & 455.0 & 690.9 & $1,105.4$ & $1,895.0$ & $2,092.4$ & $2,408.3$ \\
\hline 15 & - & - & 256.6 & 493.5 & 671.2 & 947.5 & $1,223.9$ & $1,934.5$ & $2,092.4$ & $2,447.8$ \\
\hline 16 & - & - & - & 176.4 & 513.2 & 710.6 & 1025.5 & $1,342.3$ & $1,974.0$ & $2,447.8$ \\
\hline 17 & - & - & - & 296.1 & 473.8 & 671.2 & $1,105.4$ & $1,677.9$ & $2,072.7$ & $2,408.3$ \\
\hline 18 & - & - & 276.4 & 493.5 & 690.9 & 908.6 & $1,460.3$ & $2,072.7$ & $2,289.8$ & $2,506.7$ \\
\hline 19 & - & - & - & 296.1 & 513.2 & 710.6 & $1,066.0$ & $1,855.5$ & $2,270.0$ & $2,506.7$ \\
\hline 20 & - & - & - & 276.4 & 473.8 & 671.2 & 987.0 & $1,835.8$ & $2,270.0$ & $2,506.7$ \\
\hline$\Sigma \mathrm{x}$ & & & $2,437.40$ & $7,742.1$ & $11,014.9$ & $16,266.8$ & $23,725.8$ & $37,703.0$ & $44,968.0$ & 49,4072 \\
\hline - & & & 304.67 & 372.11 & 550.75 & 813.34 & $1,248.73$ & $1,885.2$ & $2,248.4$ & $24,170.36$ \\
\hline \multicolumn{11}{|r|}{ (T) } \\
\hline & & & 81.94 & 115.30 & 86.02 & 116.59 & 191.40 & 193.25 & 146.17 & 146.44 \\
\hline $\mathrm{CV}(\%)$ & & & 26.90 & 30.98 & 15.62 & 1.43 & 1.53 & 10.25 & 6.50 & 1.88 \\
\hline
\end{tabular}




\section{DISCUSSION}

There are a few reports on the gestation periods of indigenous tree crops of nutritional importance in Nigeria. Okafor (1983) reported that budded seedlings of Irvingia wombolu Aubry le Coute Ex. O Rokel, flowers and fruits within 6-7 years. Mbakwe (2005) reported that seedling of Treculia africana budded with bud woods collected when the parent stocks were in flowers, flowers and fruits within 3-4years. The findings of this study agreed with that of Mbakwe (2005). The early fruit production of the budded seedlings observed could be attributed to the physiological phase of the parent stocks which were in flowers. The budwoods used in budding the root stock possibly contained flower inducing substance, florigen.

Observation on the flowering and fruiting pattern of the trees showed that in the first phase of reproduction, the trees experienced heavy flower and total fruit abortions resulting in no fruit yield as shown in Table 1. Similar observations had been reported for different plant species by earlier researchers (Ucheagwu, 1985; Mbakwe and Nzekwe, 2005; Nzekw et al, 2006). The result further showed that in 1998, fruit yield was poor. This could be due to the production of small sized fruits containing seeds of poor commercial qualities. The result further showed that total seed yield $(\mathrm{kg})$ increased, with time (years) from 19982001 as shown in Table 1 . The results also showed that in 2002-2005, seed yield increased tremendously and steadily with the maximum yield in $2005(12.46 \mathrm{~kg})$. The results implied that the trees had attained full maturity and were likely to yield higher quantities of seeds as the trees grew. The results agreed with other observations by several authors, who reported that fruit production by trees increased with the age of the trees until the trees attained their peak of fruit production, before declining. (Wareign and Phillips, 1977; Bidwell; 1979; Okafor, 1985; Anegbeh, et al, 1996).

There are a few information on the revenue yield per tree per year for the indigenous tree crops of Nigeria. The results of this study showed that the mean market price of the seeds of Treculia african produced per tree per year, increased from three hundred and four naira, seventy kobo ( $\$ 304.70$ ) in 1998 to two thousand four hundred and seventy naira, thirty six kobo ( $¥ 2,470.36)$ in 2005 (Table 2). The results further showed that the 20 trees generated revenue of forty nine thousand, four hundred and seven naira, twenty kobo ( $\$ 49,407.20)$ in 2005 . The very high revenue yielded by the seeds of this plant is very important in planning for economic improvement. With a standard crop population of 100trees/ha. planted using $10 \times 10 \mathrm{~m}$. spacing, expectant revenue as high as eight hundred and eleven thousand, three hundred and fourty naira $(\$ 811,340.00)$ will possibly be generated annually. The knowledge of the gestation period and revenue generating capacity of indigenous tree crops like Treculia will guide the rural farmers as well as co-operative societies in planning their cropping schedules. With the current effects of the increasing population pressure, rural to urban migration, devaluation of local currencies, poverty, hunger and low quality of life in the developing countries, it is expected that research findings such as reported in this study will encourage people to at least plant 1-5 seedlings of Treculia africana. Revenue accruing from the sale of the seeds can be relied upon for sustainable alleviation of poverty and hunger.

Based on the findings of this study, it can be summarized that Treculia plants can flower and fruit within 3-4 years when budded with budwoods collected from flowering parent stock. The study has also shown that seed yield of the plant increases with the age of the tree and seeds of commercial quantities will be anticipated from the trees 5 years after the first flowering and fruiting. The very high revenue accruing from the sale of the seeds can be an assurance for poverty alleviation particularly for the rural dwellers that partly depend on the seeds as source of food and income. However, there is need for further studies to ascertain the length of time (years) the trees attain peak fruit production, so that aged ones can be replaced

\section{REFERENCES}

Anegbeh, B., Jaenick, H, Dawson, I; Oriz, R and Ladipo, O.O. (1996). Preliminary Assessment of the Fruit Production of Irvingia gabonensis. Conference Proceedings. Hortson. Vol 1:145-149.

Baiyeri, K.P. and Mbah B.N. (2006). Effects of Soilles and Soil-based Nursery Media on seedling Emergence Growth and Response to water Stress of African bread fruit (Treculia africana) African Journal of Biotechnology. 5 (15): 1405 1410.

Bidwell, R.S.S. (1979). Plant physiology $2^{\text {nd }}$ ed. Macmillian Pub. Co. Inter. London. 726 pp.

Ejiofor, M.A.N. and Okafor, J.C. (1997): Prospects for Commercial Exploitation of Nigerian Indigenous Fruits and Seeds Through Food and Industrial Products Formulations. International Tree Crop Journal. 9: 119-129. 
Mabo, O. O., Lakami, O.O, and Olusegunm O.T. (1988). Germination Ecology of Treculia Africana. Nigerian Journal of Botany. 1: 66-72.

Mbakwe, R.C (2005). The Influence of Budwood Physiology on the Gestation Period of Fruit Crops: Treculia African (African breadfruit). Journal of Agriculture and food science 3 (1): 1- 4.

Mbakwe and Nzekwe (2005). The effects of drying on seed germination of Depulped and the Undepulped Fruits of Irvingia wombolu (Verneosen). Journal of sustainable Tropical Agricultural Research 13: 32-35.

NIHORT (2008). Personal Communication.

Nzekwe, U; Ojeifor, I.M. and Emuh, F.N. (2006) Assessment of Kernel Economic Yield of Irvingia gabonensis (Wild Mango) In South-Eastern States of Nigeria. Nigerian Journal of Research and Production 8 (1): 78-83.

Nzekwe, U, Onyemelukwe, A.B. and Eze, O.I. (1993) Studies on Some Aspects of Agronomic Problems of Some Indigenous Food Crop Resources. Inter. Congress on Industrial Utilization of Tropical Plants and the Conservation of Biodiversity (DOCP) Nike-Enugu. Nigeria, April, 1993.
Okafor, J.C. (1983). Horticulturally Promising Forest Zone. Acta Horticultural 123: $185-196$.

Okafor, J.C (1985) Indigenous Fruits Production and Conservation In Nigeria, In: Proc. National fruit Production Workshop. 14-16 March 1985. FACU Ibadan, 50 62.

Okafor, J.C., Okolo, H.C. and Ejiofor, M.A.N. (1997) Strategies for the Enhancement of Utilization Potentials of Edible forest Species of Southeastern Nigeria. (Van Der Maeson et al, eds.)The Biodiversity African Plants. 684-695.

Ucheagwu, A.C. (1985). Mango (Mangifer idica) production in Nigeria. Proc. Fruit Production Workshop. 14-16 March 1985. FACU. Ibadan 63-70.

Wareing, P.F. and Phillips, I.O.J. (1977). The Control of Growth and Differentiation in Plants Pagamon Press NY. pp. 3148. 